\title{
ION CHROMATOGRAPHIC DETERMINATION OF YTTRIUM AFTER SEPARATION FROM DYSPROSIUM SIMULTANEOUSLY WITH INDIVIDUAL QUANTIFICATION OF RARE EARTH ELEMENTS
}

\author{
Sherien Hussien Ahmed \\ Nuclear Materials Authority, P.O. Box 530 El Maadi, Cairo, Egypt \\ E-mail: boutey@yahoo.com
}

\begin{abstract}
A particular ion chromatographic method for yttrium determination after separation from dysprosium simultaneously with individual quantification of rare earth elements has been modified. Selective separation of yttrium from dysprosium plus the other thirteen rare earth elements was achieved by gradient elution using oxalic / diglycolic acid eluent mixture on IonPac CS5A separating column. The separated ions were then detected using 4-(2-pyridylazo)resorcinol (PAR) at $530 \mathrm{~nm}$. The optimized method was subsequently validated by the analysis of a reference sample from Abu Rusheid area followed by its application on two geological materials from Wadi Khuda-Wadi Shut area and Abu Tartour phosphate deposits. Relative standard deviation (RSD) calculated for the analyzed samples were expressed with very low values the matter which confirms the precision of the developed method. The present work allowed the individual determination of lanthanide elements including yttrium and six heavy metal ions in an absolute time of about 110 minutes.
\end{abstract}

Keywords: Ion chromatography; Yttrium; Rare Earth Elements; Heavy Metals; Gradient Elution.

\section{INTRODUCTION}

Yttrium represents one of the rare earth elements which involve the 15 elements plus scandium [1]. It is quite often existed in nature with the lanthanides in rare earth minerals and which by no means finds as a free element [1]. Yttrium is a most significant element in frequent protruding industrial manufactures of electronics, lasers, phosphors, superconductors, and in a variety of therapeutic purposes [2]. It is additionally broadly utilized in astronavigation, nuclear energy and metallurgical industries [3]. The application of yttrium relies on its features as well as on its purity, coming about a considerable raise in the cost with request on virtue [4].

Yttrium (Y) looks like terbium (Tb) and dysprosium (Dy) in its chemical reactivity [5]. Despite the fact that lanthanides found one row below yttrium in the periodic table, the likeness in atomic radius might be credited to the lanthanide contraction [3].

The separation of yttrium from the rare earth elements REEs is extremely difficult and considered a challenging problem owing to their similar charge and ionic radii, for example, $\mathrm{Y}$ elutes very close to Dy and Ho $[3,6,7]$. This co-elution phenomenon interferes with the precise determination of Y, Dy and Ho [8]. Separation of the REEs can only be accomplished by employing complexing agents in the mobile or stationary phases, which depends on the differences in stability constants of the metal complexes [9]. Consequently, trials have been done to create or develop chromatographic methods which involves REEs separation with elution order doesn't obey that of their ionic radii. Examples of such systems involves ion chromatographic separation using sulfonic acid as a resin and nitrilotriacetic acid (NTA; $\left.\quad \mathrm{N}\left(\mathrm{CH}_{2} \mathrm{CO}_{2} \mathrm{H}\right)_{3}\right)$ solution as an eluent [10], conventional cation exchange chromatography utilizing also sulfonic acid resin and hydroxy ethylenediaminetetraacetate (HEDTA) eluent [11]. Furthermore, reversed phase-high performance liquid chromatography (RPHPLC) presented n-octanesulfonate as ion interaction reagent (IIR) and glycolate [12], or NTA [13] in addition to nitric acid eluent which has been used by silica column impregnated with iminodiacetic acid (IDA; $\left.\mathrm{HN}\left(\mathrm{CH}_{2} \mathrm{COOH}\right)_{2}\right)$ [14]. 
As formerly demonstrated, employing REE complexes with NTA in an anion exchange system, resulted in an uncommon order of REEs elution [15] where yttrium was perfectly eluted between neodymium and samarium from its neighboring elements [16]. It is really worth noting that chromatographic techniques are considered superior in separation of $\mathrm{Y}$ from other REEs owing to the immense resemblance of their chemical properties [17, 18].

In this paper, a new developed method for the selective and quantitative determination of yttrium after separation from the adjacent element, dysprosium, simultaneously with the individual determination of rare earth elements using DX-500 Ion Chromatograph was proposed. To optimize the studied technique, the influence of some parameters concerning the variation in the oxalic acid / diglycolic acid eluents concentration ratio, its introducing time and gradient flow rate have been fully investigated. The method has then to be validated by comparing the determined values for yttrium and individual rare earth elements with that of a certified reference material so that the method can be applied on two geological samples.

\section{EXPERIMENTAL}

\subsection{Apparatus and Reagents}

Dionex Ion Chromatograph (DX-500; Sunnyvale, CA, USA) was used to operate the chromatographic measurement of the ions under study. It is provided with GP40 gradient pump, AD20 absorbance detector and a $50 \mu \mathrm{L}$ loop injecting valve. Separator ion-exchange columns; Dionex IonPac CG5A guard column $(4.6 \times 50 \mathrm{~mm})$ and IonPac CS5A analytical column $(4.6 \times 250 \mathrm{~mm})$, including mixed anion and cation beds with sulfonic acid and alkanol quaternary ammonium functional groups, were used to separate the ions under considerations which were then detected utilizing 4-(2pyridylazo)resorcinol (PAR) as a post column reagent at $530 \mathrm{~nm}$. Finally, data was collected by Advanced Computer Interface System [19].

$\mathrm{NH}_{4} \mathrm{OH}$ solution and $\mathrm{HCOOH}$ acid were employed for $\mathrm{pH}$ modifications using an Orion type $\mathrm{pH}$ meter (USA). Various standard solutions of heavy metals and lanthanides have been prepared by diluting stock solutions of $1000 \mathrm{ppm}$ (Aldrich and Merck, USA). An injected synthetic solution was prepared containing $5 \mathrm{ppm}$ from each of the following six heavy metals $\left(\mathrm{Fe}^{+3}, \mathrm{Cu}, \mathrm{Ni}, \mathrm{Zn}, \mathrm{Cd}, \mathrm{Mn}\right)$ and the fifteen lanthanide elements ( $\mathrm{La}, \mathrm{Ce}, \mathrm{Pr}$, $\mathrm{Nd}, \mathrm{Sm}, \mathrm{Eu}, \mathrm{Gd}, \mathrm{Tb}, \mathrm{Dy}, \mathrm{Y}, \mathrm{Ho}, \mathrm{Er}, \mathrm{Tm}, \mathrm{Yb}$ and $\mathrm{Lu}$. Nanopure water, with specific resistance of 18.2 mega-ohm.cm (M $\Omega . \mathrm{cm})$, was used for the preparation of the eluents and the standard solutions. Pyridine-2,6-dicarboxylic acid (PDCA) and oxalic acid eluents as well as PAR were supplied from Aldrich (USA), Knoch-Light (England) and Merck (USA) respectively.

\subsection{Chromatographic Conditions}

The chromatographic separation of the study ions has been achieved using different eluents under various elution conditions. The mobile phases employed contained constant concentration of PDCA eluent for separation of the worked six heavy metal ions and diverse oxalic / diglycolic acid eluents concentration ratios for the individual determination of the lanthanide ions. Adjusting the considered eluent $\mathrm{pH}$ was set up in buffer solutions enclosing $0.1 \mathrm{M} \mathrm{NH}_{4} \mathrm{OH}$ solution and $0.05 \mathrm{M}$ $\mathrm{KOH}$. The mobile phase's flow rates were firstly set at 0.9 and $0.1 \mathrm{~mL} \mathrm{~min}{ }^{-1}$. Fixed post column reagent (PAR) concentration $(0.2 \mathrm{mM})$ was liquefied in $1 \mathrm{M} \mathrm{CH}_{3} \mathrm{COOH}$ and $3 \mathrm{M}$ $\mathrm{NH}_{4} \mathrm{OH}$ where its flow rate was kept at $0.5 \mathrm{~mL}$ $\min ^{-1}$.

\subsection{Geology of the samples}

Three different geological rock samples collected from various areas along Egypt desert were included in the application step of the study advanced procedure. On of which is from the mineralized lamprophyre dykes of $\mathrm{Abu}$ Rusheid area which considered as a reference sample. Additionally two samples; xenotime mineral from Wadi Khuda-Wadi Shut area and phosphate rock from Abu Tartur deposit were taken into consideration. An explanation of the geology of each area was listed below.

Abu Rusheid area is located at south of Eastern Desert, Egypt $50 \mathrm{~km}$ southwest of Marsa Alam on the Red Sea coast between longitude $34^{\circ} 46^{\prime}$ to $34^{\circ} 46^{\prime} 35^{\prime \prime} \mathrm{E}$ and latitude 
$24^{\circ} 37^{\prime} 16^{\prime \prime}$ to $24^{\circ} 38^{\wedge} \mathrm{N}$. From the mineralization point of view, the main rock units of Abu Rusheid area are the cataclastic group and the lamprophyre dykes cutting through it [20].

Wadi Khuda-Wadi Shut area lies in the southern zone of the Eastern Desert along the Red Sea coast. It covers a region of around $800 \mathrm{~km}^{2}$ between Latitudes $23^{\circ} 33^{\prime}-23^{\circ} 50^{\prime} \mathrm{N}$ and longitudes $35^{\circ} 05^{\prime}-35^{\circ} 26^{\prime} \mathrm{E}$. The Wadi Khuda-Wadi Shut area comprises principally of gneisses-migmatites, ophiolitic serpentinite with talc carbonate rocks and schistose metavolcanics. These rock varieties are intruded by syn to late tectonic diorite, granodiorite, ultramafic-mafic and monzogranite intrusions and dissected by post orogenic veins, dykes and quartz plug [21]. Xenotime is a natural yttrium orthophosphate mineral that usually contains small amounts of other heavy REEs such as $\mathrm{Yb}, \mathrm{Er}$ and $\mathrm{Dy}$. The mineral is tetragonal, with a hardness of 4-5 and a specific gravity of 4.4-5.1. Xenotime, a major source for heavy rare-earth elements, is recovered as a byproduct from the concentration of other heavy minerals such as monazite, zircon, ilmenite and garnet [22].

Abu Tartur deposit is situated in Eastern Sahara, in the New Valley area of the Western Desert of Egypt, $50 \mathrm{~km}^{2}$ west of El-Kharga [23]. The deposit prolongs over $100 \mathrm{~km}^{2}$ at the south-eastern corner of Abu Tartur plateau. Its middle is at $25^{\circ} 26^{\prime} \mathrm{N}$ and $30^{\circ} 02^{\prime} \mathrm{E}$. The highest of the plateau lies somewhere in the range 550 and $560 \mathrm{~m}$ above mean sea level. The lowlands and scattered hills of the depression south of the Abu Tartur plateau have a height of around 200-300 $\mathrm{m}$ above mean sea level [24]. The phosphate formation is formed of lower and upper phosphorite beds isolated by shales, glauconitic sandstone, carbonate rocks and sandstones.

\subsection{Sample Digestion}

\subsubsection{Preparation of the mineralized lamprophyre dyke and phosphate rock samples}

The Abu Rusheid mineralized lamprophyre dyke and phosphate rock samples were firstly passed through an ashing step for 10 hours at $200{ }^{\circ} \mathrm{C}$ to devastate the organic matters stuck within the samples. Following ashing, $1 \mathrm{~g}$ of each sample was mixed with a blend of concentrated nitric, hydrofluoric, and perchloric acids in a Teflon beaker and heated till dryness using hot plate. For dissolving purpose, the dried samples were transferred separately in a $50 \mathrm{~mL}$ measuring flasks using 1:1 vol ratio of $\mathrm{HNO}_{3}$ acid and nanopure water solution up to the mark.

\subsubsection{Fusion of xenotime concentrate}

Tracing the procedure described in reference [25], the following steps are implanted with modification. $0.2 \mathrm{~g}$ xenotime concentrate was mixed well with $1 \mathrm{~g}$ lithium metaborate $\left(\mathrm{LiBO}_{2}\right)$ in a platinum crucible with ratio of $1: 5$ for about 10 minutes. The crucible was then placed in the furnace where its content was transferred to PTFE beaker and heated to about 10 minutes at $700{ }^{\circ} \mathrm{C}$. The PTFE beaker is left to cool after which the molten mixture is transferred to a Pyrex beaker containing about $40 \mathrm{~mL}$ of $6 \mathrm{~N} \mathrm{HNO}_{3}$ then stirred and heated at $60{ }^{\circ} \mathrm{C}$ with hot plate magnetic stirrer for about 1 hour in order to dissolve any remaining residue. Small drops of $\mathrm{H}_{2} \mathrm{O}_{2}$ were added in order to oxidize all ions in the sample solution. Finally, the resulted solution was transferred with nanopure water into a $50 \mathrm{~mL}$ measuring flask, completed to the mark and it was then ready to be measured using the study developed ion chromatographic method [25].

\section{RESULTS AND DISCUSSION}

As commonly known from literature, separation of rare earth elements depends on the existence of the suitable ligands $\left(\mathrm{H}_{2} \mathrm{~L}\right)$ in the eluents and also on the utilization of separation analytical columns (as CG5A and CS5A) which enclose both cation and anion exchange sites [26]. The separation process is mainly dependent on the formation of $\mathrm{LnL}_{3}^{-3}$ species which resulted from the high stability constants of these ligands with the REEs [27].

In a past work [28], the author has been capable, through utilizing a blend of oxalic and diglycolic acids along with nanopure water as a mixed eluent, to separate the rare earth elements (REEs) (La, Ce, Pr, Nd, Sm, Eu, Gd, 
$\mathrm{Tb}, \mathrm{Dy}, \mathrm{Ho}, \mathrm{Er}, \mathrm{Tm}, \mathrm{Yb}$ and $\mathrm{Lu}$ ) through a gradient elution method Figure (1). This has certainly been done before by introducing PDCA eluent with a concentration of $7 \mathrm{mM}$ at pH 3.95 so as to initially elute the heavy metals $\left(\mathrm{Fe}^{+3}, \mathrm{Cu}^{+2}, \mathrm{Ni}^{+2}, \mathrm{Zn}^{+2}, \mathrm{Cd}^{+2}, \mathrm{Mn}^{+2}\right)$, in a way to keep away from any conceivable interference with the lanthanides elution and separation [29, 30]. As indicated from the demonstrated work, $\mathrm{Y}$ was coeluted in one peak with Dy, so in the present work, many trials were done to solve the problem of separation of $\mathrm{Y}$ from Dy simultaneously with individual separation of the other thirteen RREs, including variation in the oxalic acid / diglycolic acid eluents concentration ratio, its introducing time and gradient flow rate. Though, in order to investigate such objective, oxalic and diglycolic acid eluents stock solutions of $160 \mathrm{mM}$ concentration each were prepared where their $\mathrm{pH}$ solutions were adjusted at 4.04 and 4.32 respectively.

\subsection{Mixed Eluent Ratio Variation}

In the first trial of optimizing the study method, the run has been initiated with PDCA eluent until a run time of 12 minutes followed by introducing four gradients of the mixed eluent (oxalic acid/ nanopure water/ diglycolic acid) with different ratios at different retention

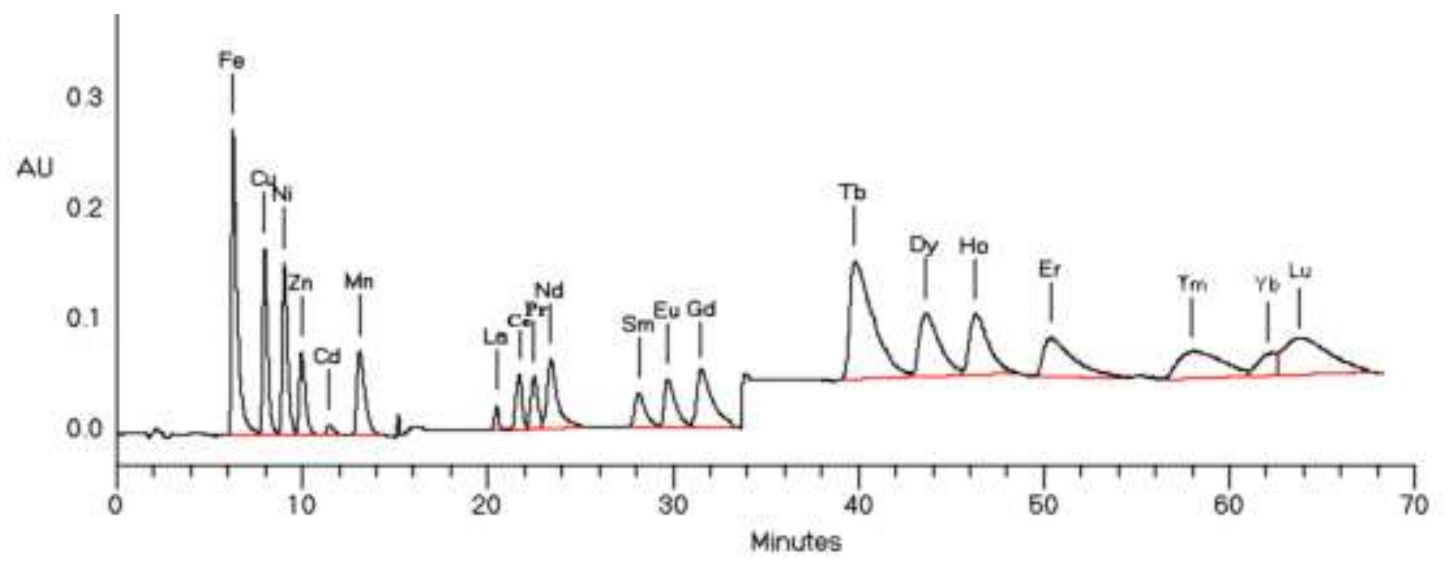

Fig. 1 Chromatogram showing the previously individual separation of the study heavy metal ions and the Rare Earth Elements [28]

Table 1 Eluent run program of the study heavy metals and REE including $\mathrm{Y}$

\begin{tabular}{|c|c|c|c|c|}
\hline$\underbrace{\text { Eluent }}_{\substack{\text { Run time } \\
(\text { min. })}}$ (conc. \& pH) & $\begin{array}{c}\text { PDCA } \\
7 \mathrm{mM}, 3.95 \\
(\%)\end{array}$ & $\begin{array}{c}\text { Oxalic acid } \\
160 \mathrm{mM}, 4.04 \\
(\%)\end{array}$ & $\begin{array}{c}\text { Nanopure Water } \\
\text { 18.2 M } \Omega . c m \\
(\%)\end{array}$ & $\begin{array}{c}\text { Diglycolic acid } \\
160 \mathrm{mM}, 4.32 \\
(\%)\end{array}$ \\
\hline Int.* & \multicolumn{4}{|c|}{ Flow rate $0.9 \mathrm{ml} / \mathrm{min}$. } \\
\hline Int.* & 100 & - & - & - \\
\hline 0.00 & 100 & - & - & - \\
\hline 12.00 & 100 & - & - & - \\
\hline 12.10 & - & 40 & 56 & 4 \\
\hline 18.00 & - & 40 & 56 & 4 \\
\hline 18.10 & - & 40 & 58 & 2 \\
\hline 24.00 & - & 40 & 58 & 2 \\
\hline 24.10 & - & 40 & 56 & 4 \\
\hline 31.00 & - & 40 & 56 & 4 \\
\hline 31.10 & - & 26 & 56 & 18 \\
\hline 33.60 & \multicolumn{4}{|c|}{ Flow rate $0.1 \mathrm{ml} / \mathrm{min}$. } \\
\hline 69.90 & - & 26 & 56 & 18 \\
\hline 70.00 & 100 & - & - & - \\
\hline
\end{tabular}

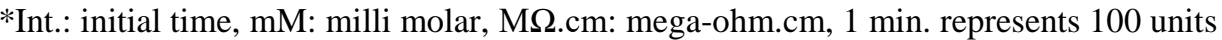


times and flow rates till the end of the run (Table 1).

By ending the run, it was observed that while the six heavy metals were eluted separately with good resolution, the fifteen lanthanide elements were however eluted in harmonic separated form but with Y overlapped with Dy in one peak (Figure 2). Therefore, it was decided to study the effect of changing the ratio of the gradient program of the used mixed eluents; namely the (oxalic acid / nanopure water / diglycolic acid) for the fourth gradient (26/56/18) respectively. These changes were directed towards decreasing the oxalic acid eluent concentration ratio while increasing that of the diglycolic acid eluent, which is considered the most effective eluent responsible for heavier lanthanides separation.
Many trials were thus performed where the chromatograms shown in Figure $(3 a, b, c)$ were obtained under the chromatographic conditions illustrated in Table (2).

As observed from the obtained chromatograms, Dy + Y peak in Figure (3a) has appeared to take a new form towards splitting which by increasing diglycolic acid eluent ratio as in Figure (3b) but with overlap of $\mathrm{Tb}$ on Dy $+\mathrm{Y}$ peak. Also, Tm, Yb and Lu were appeared to be eluted overlapped in one peak. So, thoughts were directed towards decreasing the diglycolic acid ratio and increasing the oxalic acid ratio as in Figure (3c) but the obtained chromatogram shown undesired results.

\subsection{Fourth Gradient Eluent Period Time Variation}

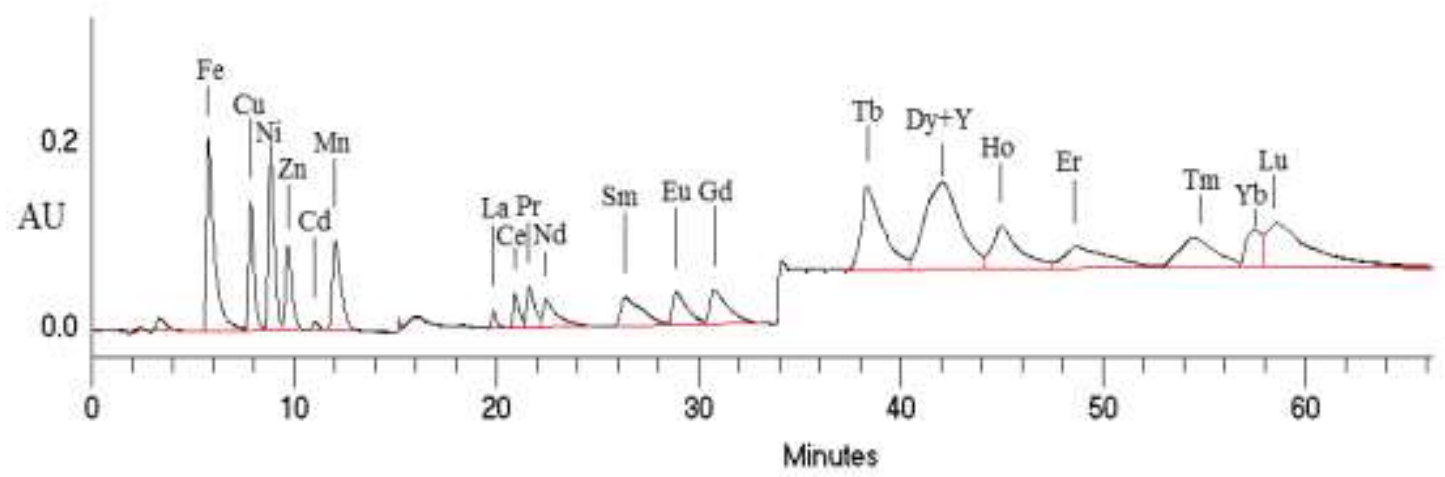

Fig. 2 Chromatogram of the study heavy metal ions and the REEs showing the overlap between Y and Dy

Table 2 Eluent run program showing the effect of mixed eluent ratio variation on $Y$ and REEs individual separation

\begin{tabular}{|c|c|c|c|c|}
\hline Run time & $\begin{array}{c}\text { PDCA } \\
7 \mathrm{mM}, 3.95 \\
(\%)\end{array}$ & $\begin{array}{c}\text { Oxalic acid } \\
160 \mathrm{mM}, 4.04 \\
(\%)\end{array}$ & $\begin{array}{c}\text { Nanopure Water } \\
\text { 18.2 M } \Omega . c m \\
(\%)\end{array}$ & $\begin{array}{c}\text { Diglycolic acid } \\
160 \mathrm{mM}, 4.32 \\
(\%)\end{array}$ \\
\hline Int.* & \multicolumn{4}{|c|}{ Flow rate $0.9 \mathrm{ml} / \mathrm{min}$. } \\
\hline Int.* & 100 & - & - & - \\
\hline 0.00 & 100 & - & - & - \\
\hline 12.00 & 100 & - & - & - \\
\hline 12.10 & - & 40 & 56 & 4 \\
\hline 18.00 & - & 40 & 56 & 4 \\
\hline 18.10 & - & 40 & 58 & 2 \\
\hline 24.00 & - & 40 & 58 & 2 \\
\hline 24.10 & - & 40 & 56 & 4 \\
\hline 31.00 & - & 40 & 56 & 4 \\
\hline 31.10 & - & $22 / 18 / 30$ & 56 & $22 / 26 / 14$ \\
\hline 33.60 & \multicolumn{4}{|c|}{ Flow rate $0.1 \mathrm{ml} / \mathrm{min}$. } \\
\hline 69.90 & - & $22 / 18 / 30$ & 56 & $22 / 26 / 14$ \\
\hline 70.00 & 100 & - & - & - \\
\hline
\end{tabular}

*Int.: initial time, mM: milli molar, M $\Omega . c m:$ mega-ohm.cm, 1 min. represents 100 units 

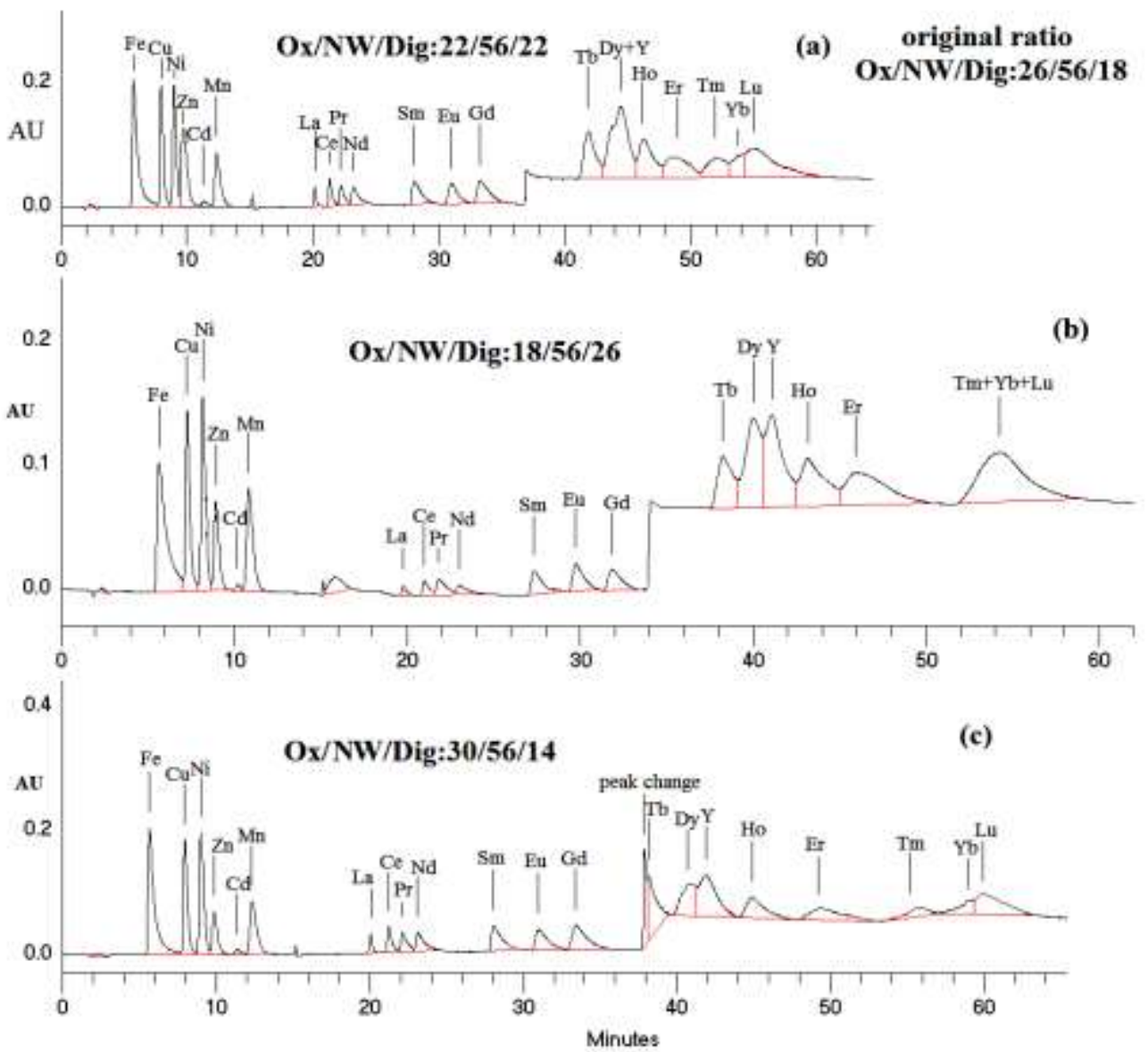

Fig. 3 Chromatogram showing the effect of mixed eluent ratio variation on $Y$ and REEs individual separation

As concluded from the above trials, $\mathrm{Y}$ separation from Dy didn't achieved, therefore, the author directed the thought towards changing the fourth gradient eluent period time from 2.5 minutes to 2,3 , and 4 minutes in order increase the effect of the eluent concentration ratio. So modifying the conditions in Table (2), where the fourth gradient eluent ratio (26/56/18) for (oxalic acid / nanopure water / diglycolic acid) respectively was introduced from retention time $31.10-33.10 \mathrm{~min}$., from 31.10 - $34.10 \mathrm{~min}$. and from 31.10 - $35.10 \mathrm{~min}$. for 2, 3, 4 minutes period time respectively. The resulted chromatograms were as obtained in Figure $4(a, b, c)$.

Investigations from the obtained chromatograms indicated that decreasing the fourth gradient eluent period time as in Figure 4a resulting in overlapping of Gd peak with the peak change in addition to eluting the peaks from $\mathrm{Tb}-\mathrm{Lu}$ with shifting to higher retention time without any effect on Dy $+\mathrm{Y}$ peak. Increasing the fourth gradient eluent period time to 3 minutes (Figure 4b) couldn't actually attribute any tangible change on Y separation. Further increasing in period time to 4 minutes as observed from Figure $4 \mathrm{c}$ resulted in great overlap between the peaks from $\mathrm{Tb}$ - Lu where Tb peak eluted in a manner overlapped with the change peak as also appeared between $\mathrm{Tm}, \mathrm{Yb}$ and Lu. Dy + Y peaks showed small splitting.

\subsection{Fourth Gradient Eluent and $0.1 \mathrm{ml} / \mathrm{min}$ Flow Rate Introducing Time Change}

By reviewing the above studied variation factors and after some unsuccessful trials, it can be pointed out that $\mathrm{Y}$ peak didn't separated from Dy peak either by variation of the mixed eluent ratio or fourth gradient eluent period time. So, in order to realize an improvement in the separation of the Y peak from the collective peak Dy $+Y$, the author targeted her thought, in the next trial, to return to the starting 
conditions in Table (1) and to change the introducing time of both of the fourth gradient mixed eluent (from 31.10 to be $24.10 \mathrm{~min}$.) and $0.1 \mathrm{ml} / \mathrm{min}$. flow rate (from 33.60 to be 26.10 min.) deleting the third gradient eluent (40/56/4) for (oxalic acid / nanopure water / diglycolic acid) respectively to be as illustrated in Table (3). The resulted chromatogram was as shown in Figure (5).

From the obtained chromatogram (Figure 5), it was resulted that "Y" peak was separately eluted in a better manner than that in the selected chromatogram of Figure (2) where the collective peak $(\mathrm{Dy}+\mathrm{Y})$ was clearly splitted into Dy and Y peaks with retention times 48.87 and $50.57 \mathrm{~min}$. respectively but with some overlap between them as between $\mathrm{Y}$ and Ho. Also an overlap was observed between $\mathrm{Eu}$ and Gd peaks. Other elements have been eluted in good separation behavior.

\subsection{Third Gradient Eluent Ratio Variation}

In a trial to achieve more separation between Dy, $\mathrm{Y}$ and Ho peaks as well as between Eu and Gd, the author tried to vary the ratio between the gradient of the third mixed eluent (26/56/18) for (oxalic acid / nanopure water / diglycolic acid) respectively as represented in Table (4). It was observed from the corresponding chromatograms that increasing the diglycolic acid ratio (22\%) and decreasing that of the oxalic acid $(22 \%)$ as in Figure (6a) resulted in eluting Dy and $Y$ completely overlapped in one peak with $\mathrm{Tb}$ and Ho appearing overlapped to $(\mathrm{Dy}+\mathrm{Y})$ peak but with much more extent for $\mathrm{Ho}$. $\mathrm{Yb}$ and $\mathrm{Lu}$ achieve more separation while Eu and $\mathrm{Gd}$ eluted without any change in their behavior.

Table 3 Eluent run program showing the effect of changing both the introducing time of the fourth gradient eluent and $0.1 \mathrm{ml} / \mathrm{min}$. flow rate on $\mathrm{Y}$ and REEs individual separation

\begin{tabular}{|c|c|c|c|c|}
\hline Run time $($ Eluent & $\begin{array}{c}\text { PDCA } \\
7 \mathrm{mM}, 3.95 \\
(\%)\end{array}$ & $\begin{array}{c}\text { Oxalic acid } \\
160 \mathrm{mM}, 4.04 \\
(\%)\end{array}$ & $\begin{array}{c}\text { Nanopure Water } \\
\text { 18.2 M } \Omega . c m \\
(\%)\end{array}$ & $\begin{array}{c}\text { Diglycolic acid } \\
160 \mathrm{mM}, 4.32 \\
(\%)\end{array}$ \\
\hline Int.* & \multicolumn{4}{|c|}{ Flow rate $0.9 \mathrm{ml} / \mathrm{min}$} \\
\hline Int.* & 100 & - & - & - \\
\hline 0.00 & 100 & - & - & - \\
\hline 12.00 & 100 & - & - & - \\
\hline 12.10 & - & 40 & 56 & 4 \\
\hline 18.00 & - & 40 & 56 & 4 \\
\hline 18.10 & - & 40 & 58 & 2 \\
\hline 24.00 & - & 40 & 58 & 2 \\
\hline 24.10 & - & 26 & 56 & 18 \\
\hline 26.10 & - & 26 & 56 & 18 \\
\hline 26.20 & \multicolumn{4}{|c|}{ Flow rate $0.1 \mathrm{ml} / \mathrm{min}$. } \\
\hline 69.90 & - & 26 & 56 & 18 \\
\hline 70.00 & 100 & - & - & - \\
\hline
\end{tabular}

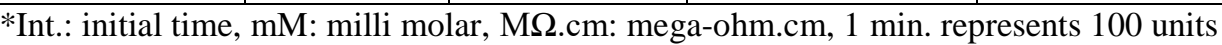

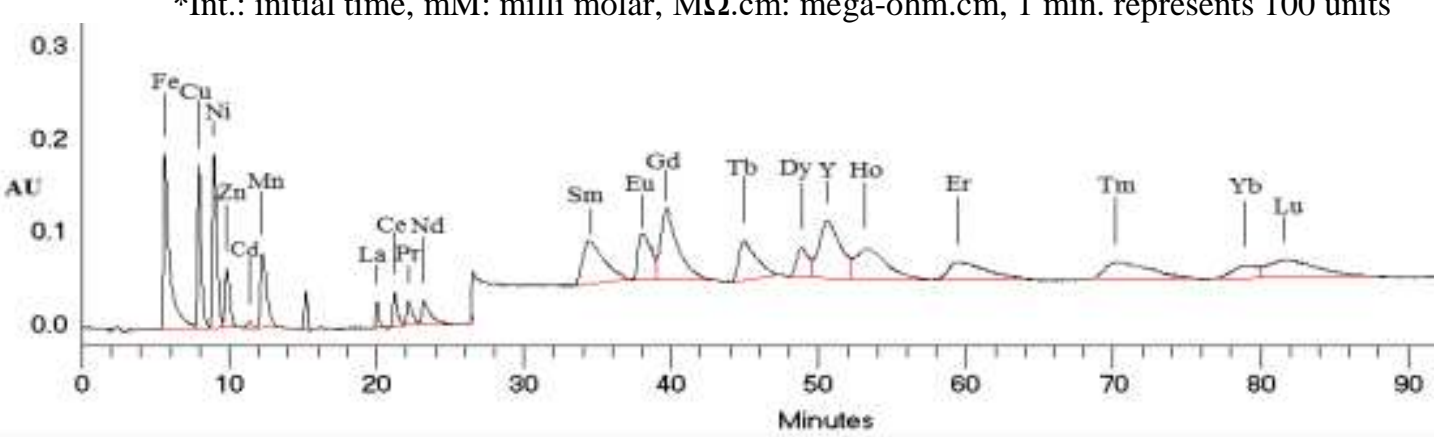

Fig. 5 Chromatogram showing the effect of changing the introducing time of both of the fourth gradient eluent as well as $0.1 \mathrm{ml} / \mathrm{min}$. flow rate on $\mathrm{Y}$ and REEs individual separation 
Table 4 Eluent run program showing the effect of third gradient eluent ratio variation on $\mathrm{Y}$ and REEs individual separation

\begin{tabular}{|c|c|c|c|c|}
\hline$\underbrace{\text { Eluent }}_{\substack{\text { Run time } \\
\text { Ein. })}}($ conc. \& pH) & $\begin{array}{c}\text { PDCA } \\
7 \mathrm{mM}, 3.95 \\
(\%)\end{array}$ & $\begin{array}{c}\text { Oxalic acid } \\
160 \mathrm{mM}, 4.04 \\
(\%)\end{array}$ & $\begin{array}{c}\text { Nanopure Water } \\
\text { 18.2 M } \Omega . c m \\
(\%)\end{array}$ & $\begin{array}{c}\text { Diglycolic acid } \\
160 \mathrm{mM}, 4.32 \\
(\%)\end{array}$ \\
\hline Int.* & \multicolumn{4}{|c|}{ Flow rate $0.9 \mathrm{ml} / \mathrm{min}$} \\
\hline Int.* & 100 & - & - & - \\
\hline 0.00 & 100 & - & - & - \\
\hline 12.00 & 100 & - & - & - \\
\hline 12.10 & - & 40 & 56 & 4 \\
\hline 18.00 & - & 40 & 56 & 4 \\
\hline 18.10 & - & 40 & 58 & 2 \\
\hline 24.00 & - & 40 & 58 & 2 \\
\hline 24.10 & - & $22 / 29 / 32 / 34$ & 56 & $22 / 15 / 12 / 10$ \\
\hline 26.10 & - & $22 / 29 / 32 / 34$ & 56 & $22 / 15 / 12 / 10$ \\
\hline 26.20 & \multicolumn{4}{|c|}{ Flow rate $0.1 \mathrm{ml} / \mathrm{min}$. } \\
\hline 99.90 & - & $22 / 29 / 32 / 34$ & 56 & $22 / 15 / 12 / 10$ \\
\hline 100.00 & 100 & - & - & - \\
\hline
\end{tabular}

*Int.: initial time, mM: milli molar, M $\Omega . c m:$ mega-ohm.cm, 1 min. represents 100 units

Trying to go in the opposite direction i.e. increasing the oxalic acid eluent ratio (29\%) and decreasing that of the diglycolic acid (15\%) (Figure 6b), created good separation between all the peaks either between $\mathrm{Eu}$ and $\mathrm{Gd}$ or between Dy, Y and Ho in addition to complete separation of $\mathrm{Tb}$ peak but $\mathrm{Yb}$ and $\mathrm{Lu}$ peaks are not eluted. Completing the in the same direction, chromatogram (6c) appeared significant separation for all the peaks including $\mathrm{Eu}, \mathrm{Gd}, \mathrm{Tb}, \mathrm{Dy}, \mathrm{Y}, \mathrm{Ho}$ but the run ended without eluting $\mathrm{Er}, \mathrm{Yb}$ and $\mathrm{Lu}$ due to eluting all the worked peaks with shifting to higher retention time. Going through more increasing in oxalic acid eluent ratio with decreasing of that of the diglycolic acid (Figure 6d) appeared good separation for $\mathrm{Eu}, \mathrm{Gd}$ and $\mathrm{Tb}$ but great overlap took place again between Dy, Y and Ho.

From the resulted trials concerning variation in the eluents ratio in the third gradient, it can be concluded that the best obtained chromatogram is that shown in Figure (6c). So, it was decided to take its conditions and complete the elution of $\mathrm{Er}, \mathrm{Yb}$ and $\mathrm{Lu}$ which necessitates the introduction of new eluent gradient (fourth gradient in that case) with higher concentration ratio for both the oxalic and diglycolic acid eluents than the third gradient eluent for the selected conditions.

\subsection{New Fourth Gradient Eluent Introducing Time Variation}

New fourth gradient eluent ratio is decided to be introduced to the selected chromatogram (Figure 6c) conditions with higher concentration ratio to be $(22 / 56 / 22)$ for (oxalic acid / nanopure water / diglycolic acid) respectively with different introducing times at 45, 52 and 55 minutes. Under these conditions the obtained chromatograms indicated that these working conditions have been able to successfully separate all the worked peaks in a manner better than that in Figure (6c) but with some overlap between $\mathrm{Y}$ and Ho. Best chromatogram obtained from these conditions is shown in Figure (7) and its conditions are represented in Table (5).

\subsection{The Fourth Gradient Eluent Ratio Change}

Trying to realize a better separation for all the peaks especially between Y and Ho, another trial was performed in which the ratio of the applied fourth gradient eluents was changed to $26 \% / 56 \% / 18 \%$ for the oxalic acid eluent/nanopure water/diglycolic acid eluent 
respectively i.e. decreasing the latter at the

So in this way, by identifying all the

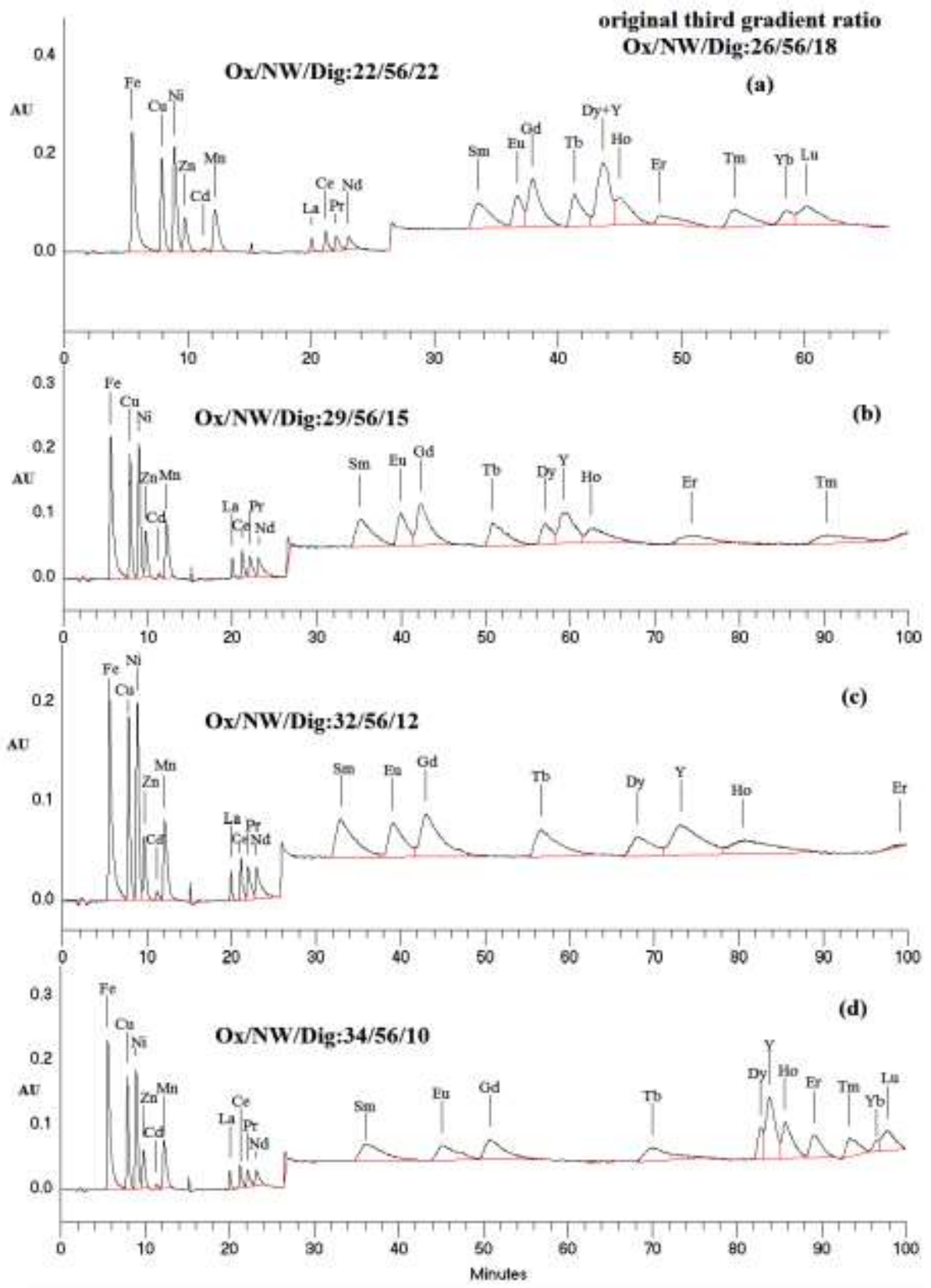

Fig. 6 Chromatogram showing the effect of third gradient eluent ratio variation on $Y$ and REEs individual separation

expense of the former (Table 6). From the obtained corresponding chromatogram shown in Figure (8), it was revealed that changing the fourth gradient eluent ratio has actually attained a high degree of perfection where it has expressed an adequately excellent separation for all lanthanide elements from ( $\mathrm{La}-\mathrm{Lu}$ ) including $\mathrm{Y}$ as well as the studied heavy metals. separated peaks expressed in Figure (8), the author had accomplished the point of the current research where the final optimized chromatogram conditions were represented in Table (6).

\subsection{Calibration of the Optimized Study Method}

After achieving optimization of the developed ion chromatographic method, calibration was occurred using various standard 
solutions of the study heavy metal ions ranging from 1-10 ppm as well as for the lanthanides ( $\mathrm{La}, \mathrm{Ce}, \mathrm{Pr}, \mathrm{Nd}, \mathrm{Sm}, \mathrm{Eu}, \mathrm{Gd}, \mathrm{Tb}$ ) whereas for the other heavy lanthanides (Dy, Y, Ho, Er, $\mathrm{Tm}, \mathrm{Yb}, \mathrm{Lu})$, concentrations from 1-6.3 ppm were prepared. As presented from the data given in Table (7), good linear relations with high correlation coefficients have been observed for each element.

\subsection{Validation, Application and Performance of the Optimized Study Method}

In the wake of improving the studied ion chromatographic method for the individual determination of some heavy metals and $\mathrm{Y}$ simultaneously with the other fourteen rare earth elements as presented in Figure (8), consequently, validation and application of the considered optimized conditions (Table 6) upon three Egyptian geological materials has been occurred. These study geological materials have included three samples; the first one is signified as a reference sample gathered from the mineralized lamprophyre dykes of $\mathrm{Abu}$ Rusheid area (South Eastern Desert of Egypt) and has been analyzed by the ACME Analytical Laboratories Limited, Vancouver, Canada by ICP-MS (Agilent 7900) technique. The second sample is xenotime mineral from Wadi Khuda-Wadi Shut area (South Eastern

Table 5 Eluent run program showing the effect of introducing the new fourth gradient eluent at 55 minute in run time on $\mathrm{Y}$ and REEs individual separation

\begin{tabular}{|c|c|c|c|c|}
\hline$\underbrace{\text { Eluent }}_{\substack{\text { Run time } \\
(\min .)}}($ conc. \& pH) & $\begin{array}{c}\text { PDCA } \\
7 \mathrm{mM}, 3.95 \\
(\%)\end{array}$ & $\begin{array}{c}\text { Oxalic acid } \\
160 \mathrm{mM}, 4.04 \\
(\%)\end{array}$ & $\begin{array}{c}\text { Nanopure Water } \\
\text { 18.2 M } \Omega . c m \\
(\%)\end{array}$ & $\begin{array}{c}\text { Diglycolic acid } \\
160 \mathrm{mM}, 4.32 \\
(\%)\end{array}$ \\
\hline Int.* & \multicolumn{4}{|c|}{ Flow rate $0.9 \mathrm{ml} / \mathrm{min}$} \\
\hline Int.* & 100 & - & - & - \\
\hline $\mathbf{0 . 0 0}$ & 100 & - & - & - \\
\hline 12.00 & 100 & - & - & - \\
\hline 12.10 & - & 40 & 56 & 4 \\
\hline 18.00 & - & 40 & 56 & 4 \\
\hline 18.10 & - & 40 & 58 & 2 \\
\hline 24.00 & - & 40 & 58 & 2 \\
\hline 24.10 & - & 32 & 56 & 12 \\
\hline 26.10 & - & 32 & 56 & 12 \\
\hline 26.20 & \multicolumn{4}{|c|}{ Flow rate $0.1 \mathrm{ml} / \mathrm{min}$. } \\
\hline 55.10 & - & 32 & 56 & 12 \\
\hline 55.20 & & 22 & 56 & 22 \\
\hline 99.90 & - & 22 & 56 & 22 \\
\hline 100.00 & 100 & - & - & - \\
\hline
\end{tabular}

*Int.: initial time, mM: milli molar, M $\Omega . c m$ : mega-ohm.cm, 1 min. represents 100 units

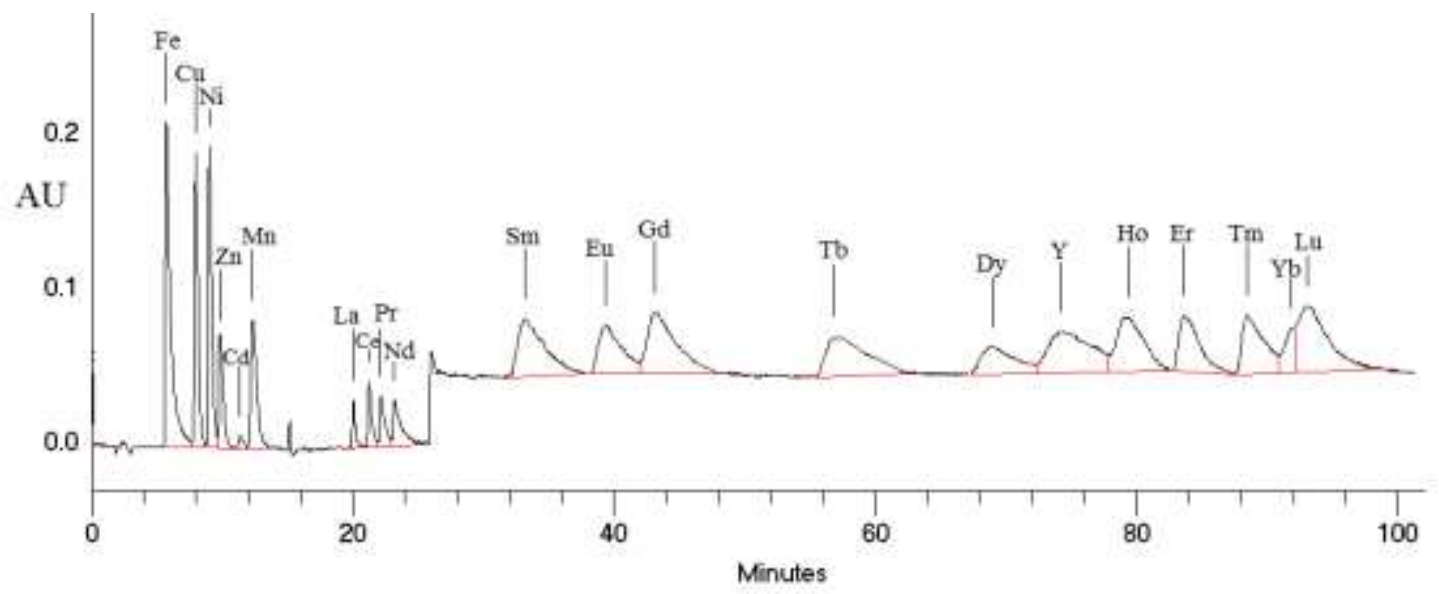

Fig. 7 Chromatogram showing the effect of introducing the new fourth gradient eluent at 55 minute in run time on $\mathrm{Y}$ and REEs individual separation 
Table 6 Eluent run program showing the effect of changing the fourth gradient eluent ratio to (26/56/18) for (oxalic acid / nanopure water / diglycolic acid) respectively on Y and REEs individual separation (optimum run program conditions for the developed method)

\begin{tabular}{|c|c|c|c|c|}
\hline$\underbrace{\text { Eluent }}_{\substack{\text { Run time } \\
(\min .)}}$ (conc. \& pH) & $\begin{array}{c}\text { PDCA } \\
7 \mathrm{mM}, 3.95 \\
(\%)\end{array}$ & $\begin{array}{c}\text { Oxalic acid } \\
160 \mathrm{mM}, 4.04 \\
(\%)\end{array}$ & $\begin{array}{c}\text { Nanopure Water } \\
\text { 18.2 M } \Omega . c m \\
(\%)\end{array}$ & $\begin{array}{c}\text { Diglycolic acid } \\
160 \mathrm{mM}, 4.32 \\
(\%)\end{array}$ \\
\hline Int.* & \multicolumn{4}{|c|}{ Flow rate $0.9 \mathrm{ml} / \mathrm{min}$} \\
\hline Int.* & 100 & - & - & - \\
\hline 0.00 & 100 & - & - & - \\
\hline 12.00 & 100 & - & - & - \\
\hline 12.10 & - & 40 & 56 & 4 \\
\hline 18.00 & - & 40 & 56 & 4 \\
\hline 18.10 & - & 40 & 58 & 2 \\
\hline 24.00 & - & 40 & 58 & 2 \\
\hline 24.10 & - & 32 & 56 & 12 \\
\hline 26.10 & - & 32 & 56 & 12 \\
\hline 26.20 & \multicolumn{4}{|c|}{ Flow rate $0.1 \mathrm{ml} / \mathrm{min}$. } \\
\hline 55.10 & - & 32 & 56 & 12 \\
\hline 55.20 & & 26 & 56 & 18 \\
\hline 119.90 & - & 26 & 56 & 18 \\
\hline 120.00 & 100 & - & - & - \\
\hline
\end{tabular}

*Int.: initial time, mM: milli molar, MS.cm: mega-ohm.cm, 1 min. represents 100 units

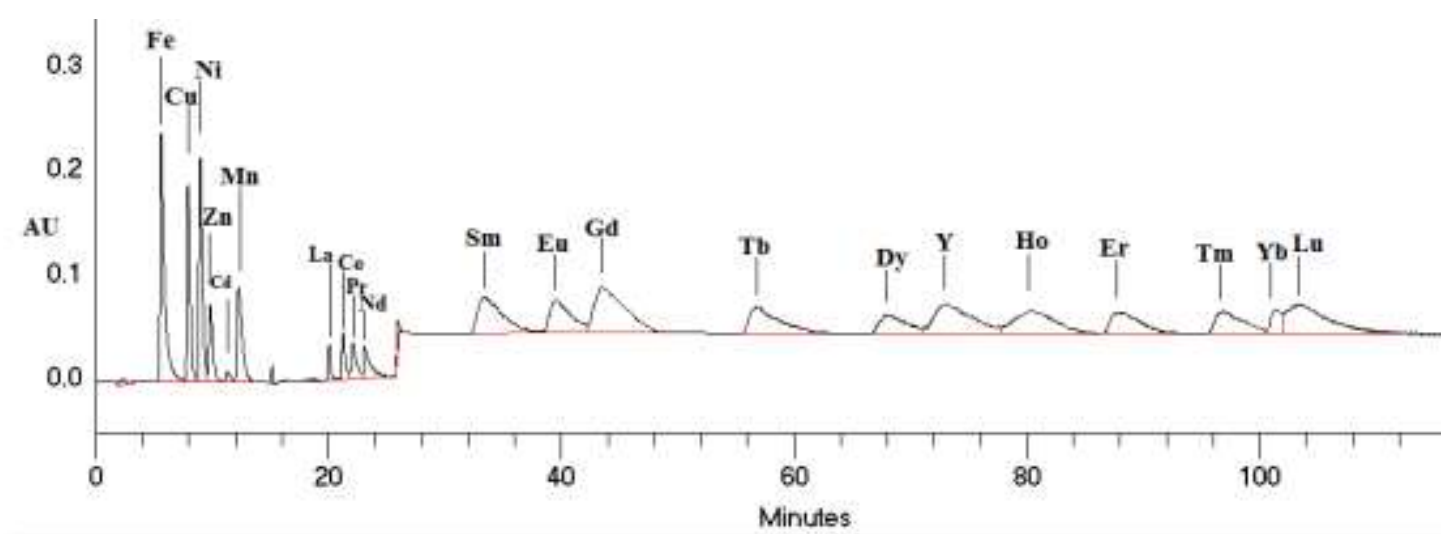

Fig. 8 Chromatogram showing the effect of changing the fourth gradient eluent ratio to (26/56/18) for (oxalic acid / nanopure water / diglycolic acid) respectively on Y and REEs individual separation (optimum chromatogram for the developed method)

Table 7 Correlation coefficients values of the studied heavy metal ions and the rare earth elements

\begin{tabular}{|c|c|c|c|c|c|}
\hline $\begin{array}{c}\text { Heavy } \\
\text { Metals } \\
\text { Ions }\end{array}$ & $\begin{array}{c}\text { Correlation } \\
\text { Coefficients } \\
\left.\mathbf{( R}^{\mathbf{2}}\right)\end{array}$ & $\begin{array}{c}\text { Rare } \\
\text { Earth } \\
\text { Elements }\end{array}$ & $\begin{array}{c}\text { Correlation } \\
\text { Coefficients } \\
\left.\mathbf{( R}^{\mathbf{2}}\right)\end{array}$ & $\begin{array}{c}\text { Rare } \\
\text { Earth } \\
\text { Elements }\end{array}$ & $\begin{array}{c}\text { Correlation } \\
\text { Coefficients } \\
\left(\mathbf{R}^{\mathbf{2}}\right)\end{array}$ \\
\hline $\mathrm{Fe}^{+3}$ & 0.9986 & $\mathrm{La}$ & 0.9904 & $\mathrm{Dy}$ & 0.9988 \\
\hline $\mathrm{Cu}$ & 0.9997 & $\mathrm{Ce}$ & 0.9918 & $\mathbf{Y}$ & $\mathbf{0 . 9 9 5 9}$ \\
\hline $\mathrm{Ni}$ & 0.9966 & $\mathrm{Pr}$ & 0.9942 & $\mathrm{Ho}$ & 0.9945 \\
\hline $\mathrm{Zn}$ & 0.9968 & $\mathrm{Nd}$ & 0.9957 & $\mathrm{Er}$ & 0.9929 \\
\hline $\mathrm{Cd}$ & 0.9998 & $\mathrm{Sm}$ & 0.9987 & $\mathrm{Tm}$ & 0.9931 \\
\hline $\mathrm{Mn}$ & 0.9997 & $\mathrm{Eu}$ & 0.9992 & $\mathrm{Yb}$ & 0.9933 \\
\hline & & $\mathrm{Gd}$ & 0.9979 & $\mathrm{Lu}$ & 0.9959 \\
\hline & & $\mathrm{Tb}$ & 0.9971 & & \\
\hline
\end{tabular}


Desert of Egypt) whereas the third one represents a sample from $\mathrm{Abu}$ Tartour phosphate deposits (Western Desert of Egypt).

The results obtained from the comparison of the reference Abu Rusheid sample which was analyzed by both ACME Lab. using ICPMS and the currently developed ion chromatographic method has been demonstrated in Table (8). It is obviously apparent that there is a nearly good agreement between the two procedures.

Table 8 Comparison of the analyzed results of the Abu Rusheid lamprophyre dykes sample for the individual determination of the heavy metal ions, Y and the REEs.

\begin{tabular}{|c|c|c|c|}
\hline Elements & $\begin{array}{c}\text { ACME } \\
\text { Lab. } \\
\text { ICP-MS } \\
\text { (ppm) }\end{array}$ & $\begin{array}{c}\text { IC } \\
\text { Procedure } \\
(\mathrm{ppm})\end{array}$ & $\begin{array}{c}\text { RSD* } \\
(\%)\end{array}$ \\
\hline \multicolumn{4}{|l|}{ Heavy } \\
\hline Metals & N.A & $5.49 \%$ & \pm 0.051 \\
\hline $\mathrm{Fe}$ & 350.7 & 340.7 & \pm 0.022 \\
\hline $\mathrm{Cu}$ & 6.40 & 5.90 & \pm 0.043 \\
\hline $\mathrm{Ni}$ & 6876 & 6865.1 & \pm 0.015 \\
\hline $\mathrm{Zn}$ & 11.60 & 10.77 & \pm 0.034 \\
\hline $\mathrm{Cd}$ & N.A. & 1561.2 & \pm 0.027 \\
\hline \multicolumn{4}{|l|}{$\mathrm{Mn}$} \\
\hline \multicolumn{4}{|l|}{ REE } \\
\hline La & 172.9 & 160.3 & \pm 0.048 \\
\hline $\mathrm{Ce}$ & 168.7 & 164.8 & \pm 0.015 \\
\hline $\operatorname{Pr}$ & 119.2 & 115.8 & \pm 0.032 \\
\hline $\mathrm{Nd}$ & 432.7 & 426.8 & \pm 0.024 \\
\hline $\mathrm{Sm}$ & 169.1 & 165.2 & \pm 0.051 \\
\hline $\mathrm{Eu}$ & 6.00 & 5.20 & \pm 0.022 \\
\hline $\mathrm{Gd}$ & 223.8 & 221.5 & \pm 0.045 \\
\hline $\mathrm{Tb}$ & 43.43 & 40.21 & \pm 0.031 \\
\hline Dy & 532.4 & 533.6 & \pm 0.017 \\
\hline $\mathbf{Y}$ & 4077 & 4074.8 & \pm 0.026 \\
\hline Ho & 152.6 & 149.7 & \pm 0.014 \\
\hline $\mathrm{Er}$ & 734.7 & 730.2 & \pm 0.033 \\
\hline $\mathrm{Tm}$ & 141.8 & 138.3 & \pm 0.043 \\
\hline $\mathrm{Yb}$ & 1268.2 & 1260.7 & \pm 0.027 \\
\hline $\mathrm{Lu}$ & 157.30 & 151.9 & \pm 0.041 \\
\hline
\end{tabular}

The study advanced ion chromatographic method was then additionally applied for the individual determination of some heavy metals, $\mathrm{Y}$ and the other fourteen rare earth elements on the two considered samples (xenotime mineral and Abu Tartur phosphate rock) as investigated in Table (9).
Table 9 Analyzed results of xenotime and Abu Tartur phosphate rock samples for the individual determination of the heavy metal ions, $\mathrm{Y}$ and the REEs.

\begin{tabular}{|c|c|c|c|c|}
\hline Elements & $\begin{array}{c}\text { Xenotime } \\
\text { Sample } \\
(\mathbf{p p m})\end{array}$ & $\begin{array}{c}\text { RSD* } \\
(\boldsymbol{\%})\end{array}$ & $\begin{array}{c}\text { Phosphate } \\
\text { Rock Sample } \\
(\mathbf{p p m})\end{array}$ & $\begin{array}{c}\text { RSD* } \\
(\boldsymbol{\%})\end{array}$ \\
\hline $\begin{array}{c}\text { Heavy } \\
\text { Metals }\end{array}$ & 55000 & \pm 0.055 & $3.11 \%$ & \pm 0.030 \\
$\mathrm{Fe}$ & 17.20 & \pm 0.027 & 10.13 & \pm 0.014 \\
$\mathrm{Cu}$ & 8.60 & \pm 0.015 & 21.45 & \pm 0.026 \\
$\mathrm{Ni}$ & 139.10 & \pm 0.023 & 132.75 & \pm 0.042 \\
$\mathrm{Zn}$ & 15.60 & \pm 0.033 & 4.10 & \pm 0.019 \\
$\mathrm{Cd}$ & 1123.41 & \pm 0.041 & 1003.3 & \pm 0.031 \\
$\mathrm{Mn}$ & & & & \\
\hline $\mathbf{R E E}$ & $\mathbf{( \% )}$ & & & \\
$\mathrm{La}$ & 0.512 & \pm 0.015 & 162.65 & \pm 0.032 \\
$\mathrm{Ce}$ & 2.360 & \pm 0.034 & 310.20 & \pm 0.012 \\
$\mathrm{Pr}$ & 0.088 & \pm 0.019 & 153.11 & \pm 0.042 \\
$\mathrm{Nd}$ & 1.457 & \pm 0.043 & 177.00 & \pm 0.016 \\
$\mathrm{Sm}$ & 0.862 & \pm 0.023 & 34.00 & \pm 0.027 \\
$\mathrm{Eu}$ & 0.086 & \pm 0.035 & 7.30 & \pm 0.022 \\
$\mathrm{Gd}$ & 2.125 & \pm 0.027 & 39.00 & \pm 0.017 \\
$\mathrm{~Tb}$ & 0.255 & \pm 0.014 & 4.30 & \pm 0.030 \\
$\mathrm{Dy}$ & 3.833 & \pm 0.022 & 36.90 & \pm 0.041 \\
$\mathbf{Y}$ & $\mathbf{2 2 . 7 2 2}$ & $\pm \mathbf{0 . 0 1 7}$ & $\mathbf{2 7 3 . 3}$ & $\pm \mathbf{0 . 0 2 5}$ \\
$\mathrm{Ho}$ & 1.091 & \pm 0.041 & 32.15 & \pm 0.036 \\
$\mathrm{Er}$ & 2.361 & \pm 0.012 & 3.90 & \pm 0.021 \\
$\mathrm{Tm}$ & 0.744 & \pm 0.025 & 2.72 & \pm 0.042 \\
$\mathrm{Yb}$ & 2.546 & \pm 0.033 & 15.10 & \pm 0.017 \\
$\mathrm{Lu}$ & 0.736 & \pm 0.027 & 1.20 & \pm 0.033 \\
\hline * Employing 3 injections in 3 independent runs \\
\end{tabular}

Performance of the currently advanced ion chromatographic method been evaluated by determining the relative standard deviation (RSD) values for the study heavy metal ions and the lanthanide elements of the three working geological samples (Tables 7, 8) where each sample was injected for three independent runs. Number of sample injections, element mean values and element standard deviation values were determined and taken in consideration for calculating RSD values.

\section{CONCLUSION}

A new chromatography procedure had been advanced for yttrium separation from dysprosium simultaneously with individual determination of rare earth elements. The method had included a unique separation system of the fifteen lanthanide elements including Y preceded by six heavy metal ions under optimization conditions of eluent's concentration and flow rate. The results obtained from the three applied geological samples acquired very low RSD percentages. The progressed method permits direct injection 
of the samples without pre-complexation and further manipulation of analytes.

\section{Disclosure statement}

The author declares that they have no conflict of interest.

\section{REFERENCES}

[1] Kifle D, Wibetoe G. Selective liquid chromatographic separation of yttrium from heavier rare earth elements using acetic acid as a novel eluent. J Chromatogr A. 2013; 1307: 86-90. doi:10.1016/j.chroma.2013.07.070.

[2] Emsley J. Yttrium, In: Nature's Building Blocks: An A-Z Guide to the Elements; Oxford University Press, Oxford, England, UK, 2001.

[3] Cotton SA. Scandium, Yttrium \& the Lanthanides: Inorganic \& Coordination Chemistry; Encyclopedia of Inorganic Chemistry, 2006. doi:10.1002/0470 862106.ia211.

[4] Sun X, Wang Y, Li D. Selective separation of yttrium by CA-100 in the presence of a complexing agent. J Alloys Compd. 2006; 408412: 999-1002. doi: 10.1016/j.jallcom.2004.12.137.

[5] Greenwood NN, Earnshaw A. Chemistry of the Elements, 2nd ed.; Oxford, ButterworthHeinemann, 1997.

[6] Verma SP, Santoyo E. High-Performance Liquid and Ion Chromatography: Separation and Quantification Analytical Techniques for Rare Earth Elements. Geostand Geoanal Res. 2007; 31(3): 161-184.

[7] Shannon RD. Revised effective ionic radii and systematic studies of interatomic distances in halides and chalcogenides. Acta Cryst. 1976; A32: 751. doi:10.1107/S0567739476001551.

[8] Santoyo E, Guevara M, Verma SP. Determination of lanthanides in international geochemical reference materials by reversedphase high-performance liquid chromatography using error propagation theory to estimate total analysis uncertainties. J Chromatogr A. 2006; 1118; 73. doi:10.1016/j.chroma.2006.01.131.

[9] Vasudeva PR, Rao N, Sivaraman TG, Srinivasan. In: Cazes, J. (ed) Lanthanides: HPLC separation, Encyclopedia of
Chromatography, 3rd ed; Taylor \& Francis, New York, 2010.

[10] Dybczyński RS, Kulisa K. Unusual elution sequence of rare earth elements (REE) in some ion chromatographic systems and the effect of temperature. Sep Sci Technol. 2011; 46: 1767. doi:10.1080/01496395.2011.572939.

[11] Strelow FVE, Victor AH. Separation of yttrium and neodymium from $\mathrm{Sm}$ and the heavier lanthanides by cation-exchange chromatography with hydroxyethylenediaminetriacetate in monochloroacetate buffer. Talanta 1990; 37: 1155. doi:10.1016/0039-9140(90)80185-I.

[12] Kuroda R, Sato K, Oguma K. Selective determination of yttrium in geological materials by ion-interaction chromatography. Microchim Acta. 1993; 110: 47. doi:10.1007/BF01243984.

[13] Kuroda R, Wada T, Kokubo Y, Oguma K. Ion interaction chromatography of nitrilotriacetato complexes of the rare earth elements with postcolumn reaction detection. Talanta 1993; 40: 237. doi:10.1016/0039-9140(93)80328-O.

[14] Nesterenko PN, Jones P. Isocratic separation of lanthanides and yttrium by high-performance chelation ion chromatography on iminodiacetic acid bonded to silica. J Chromatogr A. 1998; 804: 223-231. doi:10.1016/S00219673(97)01272-7.

[15] Dybczyński RS, Kulisa K, Pyszynska M, Bojanowska-Czajka A. New reversed phasehigh performance liquid chromatographic method for selective separation of yttrium from all rare earth elements employing nitrilotriacetate complexes in anion exchange mode. J Chromatogr A. 2015; 1386: 74. doi:10.1016/j.chroma.2015.01.091.

[16] Cotton S. Lanthanide and Actinide Chemistry; Wiley, Chichester, 2006.

[17] Nash KL, Jensen MP. Analytical-scale separations of the lanthanides: a review of techniques and fundamentals. Sep Sci Technol. 2001; 36(5\&6); 1257. doi:10.1081/SS100103649 .

[18] Chen B, He M, Zhang H, Jiang Z and Hu B. Chromatographic Techniques for Rare Earth Elements Analysis. Phys Sci Rev. 2017; 2(4). doi:10.1515/psr-2016-0057.

[19] Ahmed SH. Separation and Determination of Thorium in Uranium Mineralizations using a 
Mixed Ion Exchange Column by Ion Chromatography. Nucl Sci Scient J. 2018; 7(1): 165-176. doi: 10.21608/nssj.2018.30737.

[20] Ibrahim ME, Saleh GM, Dawood NA, Aly GM. Ocellar lamprophyre dyke bearing mineralization, Wadi Nugrus, Eastern Desert, Egypt: Geology, mineralogy and geochemical implications. Chin J Geochem. 2010; 29: 383 392. doi: 10.1007/s11631-010-0470-6.

[21] Shokry MM, Sadek MF, Osman AF, El Kalioubi BA. Precambrian basement rocks of Wadi-Khuda-Shut area, South Eastern Desert of Egypt: Geology and remote sensing analysis. Egypt. J Remote Sensing Space Sci. (2020). doi:10.1016/j.ejrs.2019.12.005.

[22] El Hady SM, Bakry AR, Al Shami AS, Fawzy MM. Processing of the xenotime concentrate of Southwestern Sinai via alkali fusion and solvent extraction. Hydrom. 2016; 163: 115-119.

[23] Harraz HZ. Uranium Resources and Reserves in Egypt. Presented at the Conference of Department of Geology, Faculty of Science, Tanta University, Egypt. doi: 10.13140/RG.2.2.17312.69124. Accessed November 2017.

[24] Notholt AJG, Sheldon RP, Davidson DF. Phosphate Deposits of the World, Phosphate Rock Resources; Cambridge University Press, 1989.

[25] Braysher E, Russell B, Woods S, García-Miranda M, Ivanov P, Bouchard B, et al. Complete dissolution of solid matrices using automated borate fusion in support of nuclear decommissioning and production of reference materials. J Radioanal Nucl Chem. 2019; 321: 183-196. https://doi.org/10.1007/s10967-01906572-z.

[26] Bruzzoniti MC, Mentasti E, Sarzanini C. Determination of lanthanides by ion chromatography. Separation and retention mechanism. Anal Chim Acta 1997; 353: 239244. doi:10.1016/S0003-2670(97)87782-3.

[27] Ahmed SH, El Gammal EM. Chromatographic Separation and Determination of Some Heavy Metals and the Sum of the Rare Earth Elements in Some Geological Materials. Chem Pap. (2020). doi: 10.1007/s11696-020-01182-6.

[28] Ahmed SH. Ion Chromatographic Separation and Quantification of Rare Earth Metals
Distribution in Some Geological Materials. Ph.D. Thesis, Ain Shams University, Faculty of Science, Cairo, Egypt, 2009.

[29] Borai E, Ekhlom P, Harjula R. Group Separation of Heavy Metals Followed By Subsequent And Individual Separation Of Lanthanides By Chelation Chromatography. J Liq Chromatogr Relat Technol. 2014; 37: 1614-1631. doi: 10. 1080/10826076. 2013. 803204.

[30] Murgia SM, Selvaggi R, Poletti A. Determination of Trace Transition Metals In Environmental Matrices By Chelation Ion Chromatography. Environ Monit Assess. 2010; 174: 313-326. doi: 10.1007/s10661-010-1459-7.
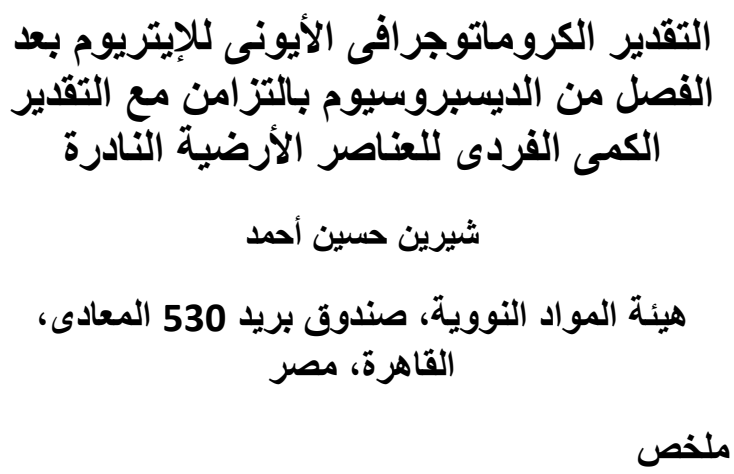

تـم تطـوير طريقـة كروماتوجر افيـة أيونيـة معينـة لتقدير

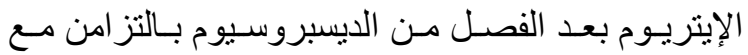
التقدير الكمى الفردي للعناصر الأرض النادرة. تم تحقيق

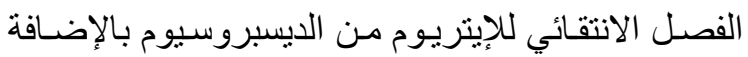
إلى العناصر الأرضية النادرة الثلاثة عشر الأخرى عن عن الأنئن

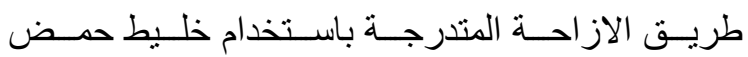

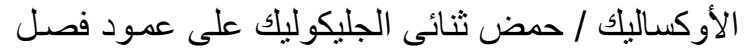

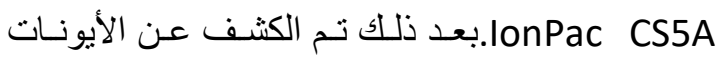
المنفصلة باستخدام4-(2- بيريديل أزو) ريسرسينول

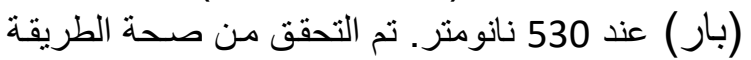

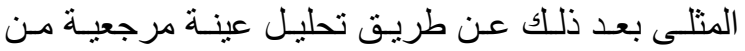

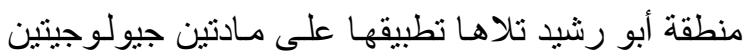

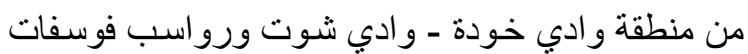
أبو طرطور. تم التعبير عن الانحر اف المعياري النسبي

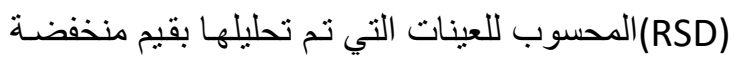
للغايـة الأمـر الذي يؤكد إحكـام الطريقة المطورة. أتـاح العمل الحالي التقدير الفردي لعناصر اللانثينيدات بما في ذلك Y وستة أيونـات معدنيـة ثقيلة في وقت مطلت يبلغ

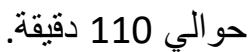

